\title{
Corrigendum: Phosphorylation of SRSF1 by SRPK1 regulates alternative splicing of tumor-related Rac1b in colorectal cells
}

VÂNIA GONÇALVES, ANDREIA F.A. HENRIQUES, JOANA F.S. PEREIRA, ANA NEVES COSTA, MARY PAT MOYER, LUÍS FERREIRA MOITA, MARGARIDA GAMA-CARVALHO, PAULO MATOS, and PETER JORDAN

In this article published in the April 2014 issue of RNA, two of the coauthors' names were incompletely spelled as Andreia Henriques and Joana Pereira but should read Andreia F.A. Henriques and Joana F.S. Pereira.

The authors regret any inconvenience that this has caused.

doi: $10.1261 /$ rna.055020.115 

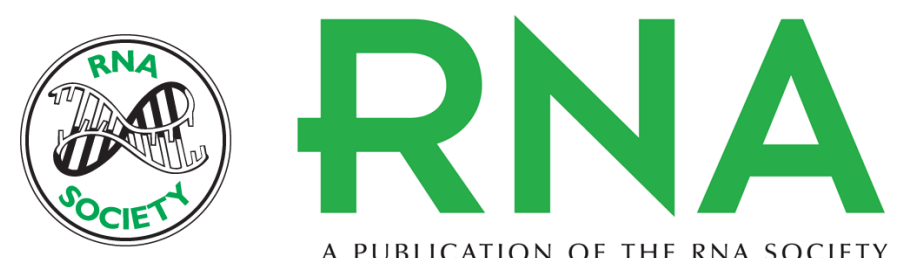

A PUBLICATION OF THE RNA SOCIETY

\section{Corrigendum: Phosphorylation of SRSF1 by SRPK1 regulates alternative splicing of tumor-related Rac1b in colorectal cells}

Vânia Gonçalves, Andreia F.A. Henriques, Joana F.S. Pereira, et al.

RNA 2016 22: 166

\section{Related Content Phosphorylation of SRSF1 by SRPK1 regulates alternative splicing of tumor-related Rac1b in colorectal cells \\ Vânia Gonçalves, Andreia Henriques, Joana Pereira, et al. \\ RNA April , 2014 20: 474-482}

Open Access Freely available online through the RNA Open Access option.

License

Email Alerting Receive free email alerts when new articles cite this article - sign up in the box at the Service top right corner of the article or click here.

To subscribe to $R N A$ go to:

http://rnajournal.cshlp.org/subscriptions 